\title{
Ireland defends research from cuts
}

\section{Government promises that despite massive deficit, last year's science budget fall will be offset by extra cash.}

\section{BY NATASHA GILBERT}

$\mathrm{I}$ $\mathrm{n}$ a world in which research budgets are plunging in step with other public spending, the Republic of Ireland is a rare exception. Even as the government prepares for an austerity budget that will try to plug a $€ 50$-billion (US\$70.4-billion) hole in its coffers, researchers are expected to be spared savage cuts.

Last month, the Irish government announced that after bailing out its banking sector, its budget deficit had ballooned to $32 \%$ of its national income - the highest among all developed nations - forcing the government to promise drastic action in it annual budget plan on 7 December.

But research should be insulated by an additional $€ 2.4$ billion for the total science, technology and engineering budget over the next five years, promised by the government in July as concerns about the budget mounted. The commitment was won after hard lobbying from science bodies. Last year, the 2009-10 allocation for research grants was cut by $4 \%$ on the previous year, bringing it to $€ 297$ million.

Science Foundation Ireland (SFI), the republic's basic-science-funding body, received about $€ 150$ million of that sum, $€ 40$ million less than it was expecting. "2010 was a tough year for the SFI," says Graham Love, director of policy and communications at the foundation. "When we opened for business we had only $€ 10$ million to spend on "Science new grants."

\section{The SFI usually spends} and research are clearly a government priority." around $30 \%$ of its budget on new grants, but this year it has cut 300 grants for $\mathrm{PhD}$ students and postdocs, and cancelled its 2010 funding round for young principal investigators.

Science leaders warned that the impact of these cuts would undermine the republic's efforts to build a knowledge economy, propelled by a doubling in science spending over the past decade. This led to the five-year funding commitment promise from the government, redressing previous cuts and reaffirming its commitment to build up its science base (see Nature 457, 1170-1171; 2009). The SFI now plans to double the number of awards for $\mathrm{PhD}$ students to 75 next year under its Research
Frontiers Programme. It also hopes to restart its programme for young investigators, awarding 20 grants in 2011. Love says he is much more optimistic about the future for science in the republic than he was this time last year, although he won't relax until the government confirms the promised funds. "We have not been given the letter from the treasury confirming our budget yet."

Desmond Fitzgerald, vice-president for research at University College Dublin, says the promised funding should go some way to offset some of the 2009-10 cuts. But he is still concerned about the longer-term impacts of the 2009-10 budget decline, which was one of the main reasons behind the university's decision to lay off about $8 \%$ of its 3,378 staff, which so far includes 82 academic posts. "My biggest concern is brain drain," says Fitzgerald. "If the struggle in funding leads to a fall in confidence it could undermine investments made over the past ten years."

David Lloyd, dean of research at Trinity College Dublin, says the university dipped into its own purse to maintain research staff levels. It launched new lectureships that were paid for out of the university's endowment, rather than public funds. "We worked hard to stand still on numbers," he says.

The government is now consulting on what key science areas it should focus funding on over the next five years. On 27 September it announced that a group led by Jim O'Hara, then general manager of Intel Ireland, a computer technology company based in County Kildare, would identify between 10 and 20 priority funding areas over the next year.

In a statement, the republic's Department of Enterprise, Trade and Innovation told Nature: "Science and research are clearly a government priority." -

\section{Quango bonfire kindles advice fears}

\section{Abolition of UK regulatory bodies could compromise independent scientific guidance.}

\section{BY DANIEL CRESSEY}

$\mathrm{P}$ lans by the British government to terminate or merge dozens of its scientific advisory and regulatory bodies drew dismayed cries from researchers earlier this year, when details first emerged. At the time, alarm focused on high-profile casualties such as the Human Fertilisation and Embryology Authority (see Nature 466, 674; 2010). But as official information on the fate of UK 'quangos' quasi-autonomous non-governmental organizations - was released last week (see 'Stoking the bonfire'), fresh fears emerged about the potential loss of independent scientific advice. Many quangos were set up to keep key regulatory functions away from political interference — or, cynics claim, to distance politicians from the controversial or unpopular recommendations that these bodies sometimes make. When the ruling Labour Party ceded power to a Conservative-Liberal Democrat coalition in May, the new government said that a 'bonfire of the quangos' would help to save money. It also claimed that absorbing advisory bodies into government departments would improve efficiency. But last week, amid warnings that cost savings might be minimal, the move was rebranded as a drive for accountability, laying tough decisions at the doors of elected politicians rather than appointed officials.

Some of the scores of senior scientists who have been members of advisory quangos are concerned about the future of independent advice under the new arrangements. "I really, really worry about where government is going to get awkward but constructive advice," says John Lawton, an ecologist and current chairman of the Royal Commission on Environmental Pollution (RCEP), which has provided independent advice since 1970, but will cease to exist in March 2011. The commission was 
- a driving force behind Britain's 1974 Control of Pollution Act, the removal of lead from petrol and government targets for reduction of carbon dioxide emissions. The RCEP is funded by the Department for Environment, Food and Rural Affairs to the tune of around $£ 1$ million (US $\$ 1.6$ million) a year.

"I think it made an enormous contribution to the development of environmental policy both in Britain and beyond," says Susan Owens, an expert on environmental governance at the University of Cambridge, UK, who served on the commission for a decade. In 2007, a review of the RCEP by PricewaterhouseCoopers, a professional-services company based in London, concluded that the government still needed the commission's advice, and that no other body had managed to replicate its "independence, scientific rigour and depth of study".

The commission has also been influential on European policy-makers, says Andrew Jordan, who researches environmental politics at the University of East Anglia in Norwich, UK. Patrick ten Brink, head of the Brussels office of the Institute for European Environmental Pol-

DNATURE.COM To view the full list of quangos and their proposed fates, see: go.nature.com/dtjjnh icy, agrees. "The RCEP has been a great source of robust, evidence-based analysis," he says. "People in Europe do look to some of the reports and

\section{STOKING THE BONFIRE}

After a review of 901 quangos and other groups, the UK government has abolished 192 agencies, merged 118 and promised to reform 171 . These include high-profile scientific regulatory or advisory bodies.

\begin{tabular}{|c|c|c|c|}
\hline Quango & Function & Fate & Annual cost \\
\hline $\begin{array}{l}\text { Human Fertilisation and } \\
\text { Embryology Authority }\end{array}$ & $\begin{array}{l}\text { Licensing and monitoring of } \\
\text { fertility clinics and embryo } \\
\text { research }\end{array}$ & $\begin{array}{l}\text { Functions 'transferred to } \\
\text { other regulators' }\end{array}$ & $£ 2$ million \\
\hline Human Tissue Authority & $\begin{array}{l}\text { Licensing and inspection of the } \\
\text { use of human tissues }\end{array}$ & Functions transferred & $£ 2$ million \\
\hline $\begin{array}{l}\text { Health Protection } \\
\text { Agency }\end{array}$ & $\begin{array}{l}\text { Advice on diseases and hazards } \\
\text { to public, government and } \\
\text { doctors }\end{array}$ & Functions transferred & $£ 222$ million \\
\hline $\begin{array}{l}\text { Sustainable } \\
\text { Development } \\
\text { Commission }\end{array}$ & $\begin{array}{l}\text { Advice on and watchdog for } \\
\text { sustainability issues }\end{array}$ & Funding ending & $£ 4.5$ million \\
\hline $\begin{array}{l}\text { Royal Commission on } \\
\text { Environmental Pollution }\end{array}$ & $\begin{array}{l}\text { Advice on pollution to } \\
\text { government and the public }\end{array}$ & Abolished & $£ 1$ million \\
\hline
\end{tabular}

discussions it has done."

Lawton notes that the RCEP chooses its own topics on which to deliver advice, unlike advisory groups that are part of government departments, whose tasks are often set by ministers. "They'll be looking where the light shines, and it depends who's holding the torch," says Jon Ayres, head of the Institute of Occupational and Environmental Medicine at the University of Birmingham, UK, and a member of the RCEP.

But some expert advisers expect the shakeup to have little impact on their work. "I've been assured that we will still be considered an independent committee," says David Phillips, chairman of the Committee on Carcinogenicity of Chemicals in Food, Consumer Products and the Environment, which will be brought into the Department of Health.

The government's chief scientific adviser, John Beddington, insists that scientific advice to government will remain free of political interference. He says that he "will be working with the departments concerned to ensure that no expert capacity is lost". 